\title{
Review
}

\section{Effects of heat stress on mammalian reproduction}

\author{
Peter J. Hansen* \\ Department of Animal Sciences, University of Florida, PO Box 110910, \\ Gainesville, FL 32611-0910, USA
}

\begin{abstract}
Heat stress can have large effects on most aspects of reproductive function in mammals. These include disruptions in spermatogenesis and oocyte development, oocyte maturation, early embryonic development, foetal and placental growth and lactation. These deleterious effects of heat stress are the result of either the hyperthermia associated with heat stress or the physiological adjustments made by the heat-stressed animal to regulate body temperature. Many effects of elevated temperature on gametes and the early embryo involve increased production of reactive oxygen species. Genetic adaptation to heat stress is possible both with respect to regulation of body temperature and cellular resistance to elevated temperature.
\end{abstract}

Keywords: heat stress; reproduction; spermatogenesis; oocyte; embryo; gestation

\section{INTRODUCTION: MAINTENANCE OF HOMEOTHERMY AND CONSEQUENCES OF REGULATION AND DYSREGULATION OF BODY TEMPERATURE FOR REPRODUCTION}

As endotherms, mammals typically function at high core body temperatures that range from approximately $35^{\circ} \mathrm{C}$ to $39^{\circ} \mathrm{C}$ (Prosser \& Heath 1991). These high temperatures, which generally exceed the temperature of the surrounding environment, are achieved through combustion of fuel stuffs to achieve a high metabolic rate (i.e. heat production). Body temperature is closely regulated by matching heat production with heat loss to the environment via conduction, convection, radiation and evaporation. The set-point temperature for regulation of body temperature is not fixed but can vary diurnally or, in some animals, as part of the hibernation response or in response to changes in environmental temperature or other cues (Heldmaier et al. 2004).

As a group, endotherms can better tolerate low body temperatures than high body temperatures. Indeed, many hibernating species maintain core body temperature at $6-10^{\circ} \mathrm{C}$ or less (Heldmaier et al. 2004). There is less resistance to body temperatures above the set-point temperature: death is likely when temperatures exceed these values by a few degrees because of disruptions in membrane fluidity, protein structure and, for animals in which sweating or panting exist, electrolyte and fluid loss. In humans, for example, set-point temperature is $37^{\circ} \mathrm{C}$ and potentially lethal effects of hyperthermia are common at body temperatures above $40-41^{\circ} \mathrm{C}$ (Jardine 2007). Not surprisingly then, regulation of core body temperature is a

*hansen@animal.ufl.edu

One contribution of 11 to a Theme Issue 'Impacts of environmental change on reproduction and development in wildlife'. priority over several other physiological functions. Regulation of body temperature in endotherms can be considered as a homeokinetic control process whereby achievement of equilibrium in body temperature involves dynamic processes that lead to perturbations in other physiological processes.

Heat stress in this paper is defined as an environment that acts to drive body temperature above set-point temperature. Heat stress can lead to disruptions in reproductive processes through two general mechanisms. First, the homeokinetic changes to regulate body temperature can compromise reproductive function. One example is redistribution of blood flow from the body core to the periphery to increase sensible heat loss. Another homeokinetic control mechanism for body temperature is reduced feed intake during heat stress. Reducing feed intake reduces metabolic heat production but also can lead to changes in energy balance and nutrient availability that can have large effects on cyclicity, establishment of pregnancy and foetal development. A second mechanism for disruption of reproduction during heat stress is the failure of homeokinetic systems to regulate reproduction. As will be seen in this paper, the rise in body temperature about its regulated set point can compromise function of germ cells, the early developing embryo, and perhaps other cells involved in reproduction. In this paper, the term heat shock will be used to describe the effects of elevated temperature on cellular function.

One objective of this paper is to describe the consequences of heat stress for specific components of the reproductive process in the male and female mammal. Most of the work on this topic has involved farm animals because of the economic consequences of heat stress in livestock systems and the paper will necessarily focus largely on these species. A second objective is to highlight the genetic plasticity of 
mammals with respect to adjusting to changes in the thermal environment. In large part, endotherms occupy a large percentage of the Earth's surface because of evolutionary advantages in maintaining a constant high body temperature in the presence of a variable environmental temperature and the effectiveness of thermoregulatory mechanisms in maintaining that body temperature. Thus, there is capacity for adaptation during both physiological and evolutionary time-scales.

\section{THE MALE}

\section{(a) Spermatogenesis}

Most mammals have testes suspended in a scrotum outside the body cavity so that intratesticular temperature is slightly lower than core body temperature. There is an intricate thermoregulatory system in the testis involving countercurrent exchange of heat from warm blood entering the testis and cool blood draining from the testis through an arterio-venous plexus called the pampiniform plexus. The degree of cooling is further controlled by two muscles: the tunica dartos in the scrotum that regulates scrotal surface area and the cremaster muscle that controls the position of the scrotum relative to the body.

It has been speculated that evolution of the scrotum occurred because of the need for low temperatures either for spermatogenesis, sperm storage or to minimize mutations in gamete DNA (Werdelin \& Nilsonne 1999; Bedford 2004). However, low body temperature is not an absolute requirement for spermatogenesis. Birds, which have body temperatures higher than mammals (Prosser \& Heath 1991), have internal testes. So do several mammalian species (figure 1). Seals, for example, have testes that have descended to the ventral body wall and which may experience some local cooling via anastomoses of veins leaving the dorsal flipper with veins supplying venous plexuses in the inguinal region (Rommel et al. 1995). Other mammals such as cetaceans (Rommel et al. 1992) and elephants (Gaeth et al. 1999) have testes that do not descend towards the inguinal region and which have temperatures that are the same as core temperature (elephant; Werdelin \& Nilsonne 1999) or are presumably the same (cetacean).

Regardless of the evolutionary reason for the location of the testis and epididymis outside the body, a rise in testicular temperature in mammals with external testes leads to reduced sperm output, decreased sperm motility and an increased proportion of morphologically abnormal spermatozoa in the ejaculate. Such effects can be observed when a local heat source is applied to the testis, the scrotum is insulated, the testes are internalized (i.e. cryptorchidism induced) or body temperature is raised because of fever or thermal environment (Setchell 1998). The cells that are most susceptible to damage are the spermatocyte and spermatid (Setchell 1998), although B spermatogonia can be damaged also (figure 2). Oxidative stress is a major cause for thermal damage of spermatogenic cells and leads to apoptosis and DNA strand breaks (Pérez-Crespo et al. 2008; Paul et al. 2008, 2009). Effects of cryptorchidism on
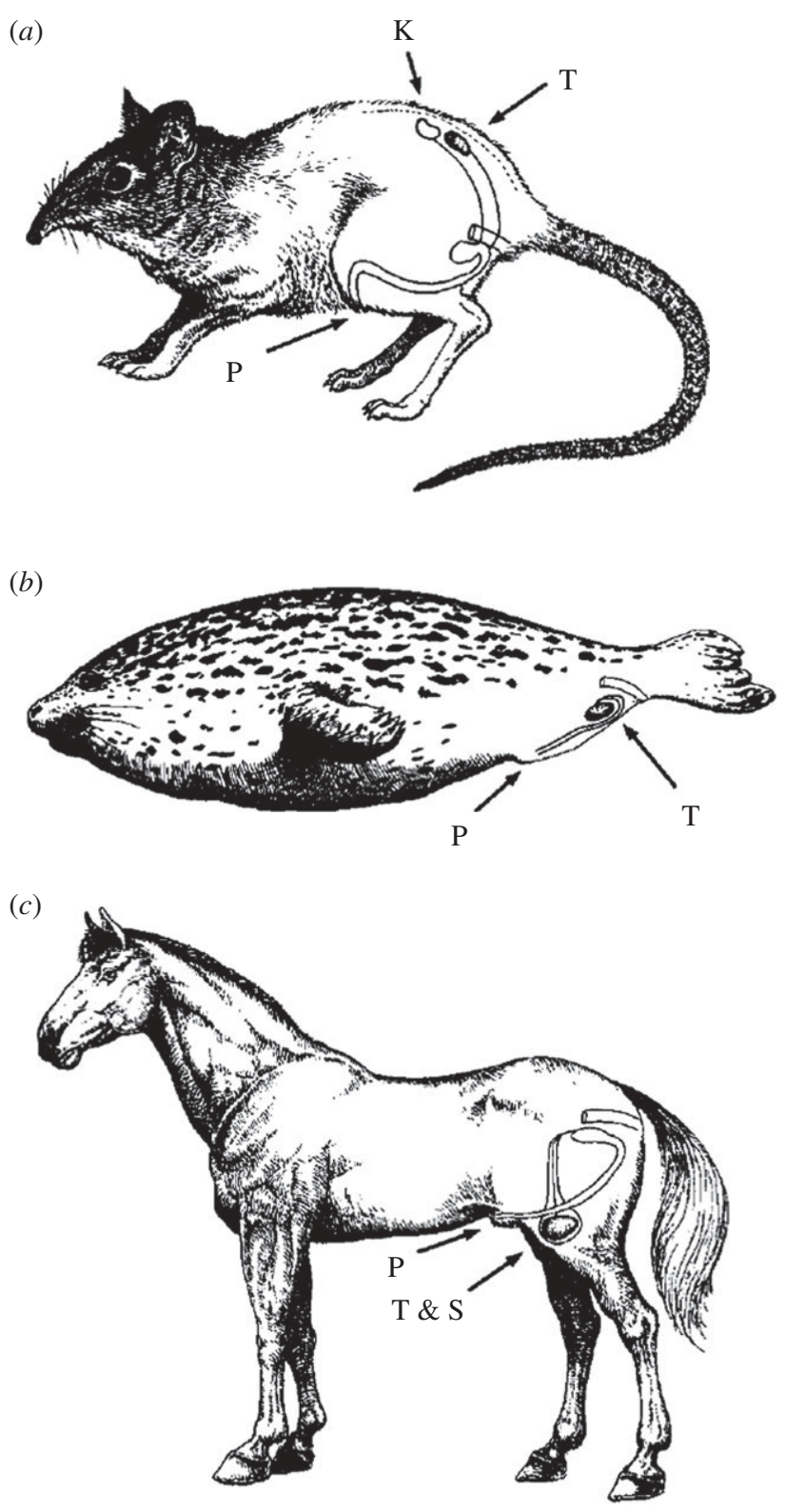

Figure 1. Variation in the location of the testes in mammals. Most mammals have testes that are located outside the abdominal cavity and that exist at a temperature a few degrees cooler than core body temperature. One example is the (c) horse. However, in some species, descent of the testis from a location caudal to the kidneys does not occur or is very limited and testes remain in the dorsal abdominal cavity. The (a) rofous elephant shrew, Elephantulus rufescens, is an example. For other species, the testes descend to the ventral abdominal wall but remain in the body cavity, as is the case for the (b) harbour seal, Phoca vitulina. T, testis; $\mathrm{K}$, kidney; P, penis; $\mathrm{T} \& \mathrm{~S}$, testis in scrotum. The figure is adapted from Werdelin \& Nilsonne (1999) with permission from fournal of Theoretical Biology.

spermatogenesis were enhanced in superoxide dismustase-1 knockout mice (Ishii et al. 2005).

There are indications that developmental competence of the resulting embryo can be reduced if fertilization is by a spermatozoon exposed to heat shock. Paul et al. (2008) reported that in vitro fertilization with sperm recovered from male mice in which the scrotum was heated to $42^{\circ} \mathrm{C}$ resulted in embryos with reduced ability to complete development. 


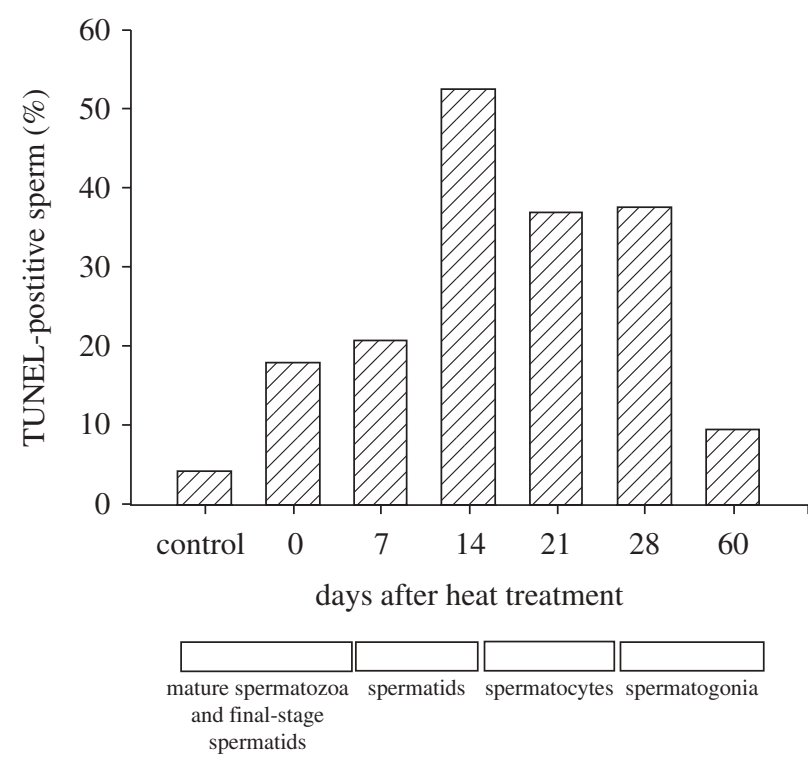

Figure 2. DNA damage in epididymal sperm collected at various times after heating of the scrotum of male mice. DNA damage was determined using the TUNEL assay. The $x$-axis indicates the days after heating when the sample was collected and the approximate stage at which recovered spermatogenic cells were when heating was applied. The figure is redrawn from Pérez-Crespo et al. (2008) with permission from Molecular Reproduction and Development.

In addition, females mated to males exposed to scrotal heating had conceptuses with smaller foetal and placental weights compared with controls (Jannes et al. 1998; Paul et al. 2008).

Semen characteristics are not immediately affected by changes in testicular temperature because damaged spermatogenic cells do not enter ejaculates for some time after heat stress. In the bull, for example, where spermatogenesis takes about 61 days, alterations in semen occur about two weeks after heat stress and do not return to normal until up to eight weeks following the end of heat stress (figure 3 ).

Data are equivocal as to whether ejaculated spermatozoa can be damaged by heat shock when deposited in the reproductive tract of a hyperthermic female. Culture of bull spermatozoa at $40^{\circ} \mathrm{C}$ did not alter fertilizing capability or the competence of the resultant embryos to develop to the blastocyst stage (Hendricks et al. 2009). In addition, ejaculated bull and stallion spermatozoa do not undergo apoptosis when cultured at temperatures characteristic of physiological hyperthermia (Hendricks \& Hansen 2009). Nonetheless, there may be epigenetic changes in embryonic development associated with damage to the sperm in the reproductive tract. Insemination of rabbit does with sperm exposed to elevated temperature in vitro (Burfening \& Ulberg 1968) or in the female reproductive tract (Howarth et al. 1965) resulted in reduced preimplantation survival and, in one study (Burfening \& Ulberg 1968), post-implantation survival. There is also evidence that $\mathrm{X}$ and $\mathrm{Y}$ spermatozoa are affected differentially by elevated temperature. The sex ratio of embryos was skewed towards female when female mice were bred to males experiencing scrotal heat treatment on the day of mating

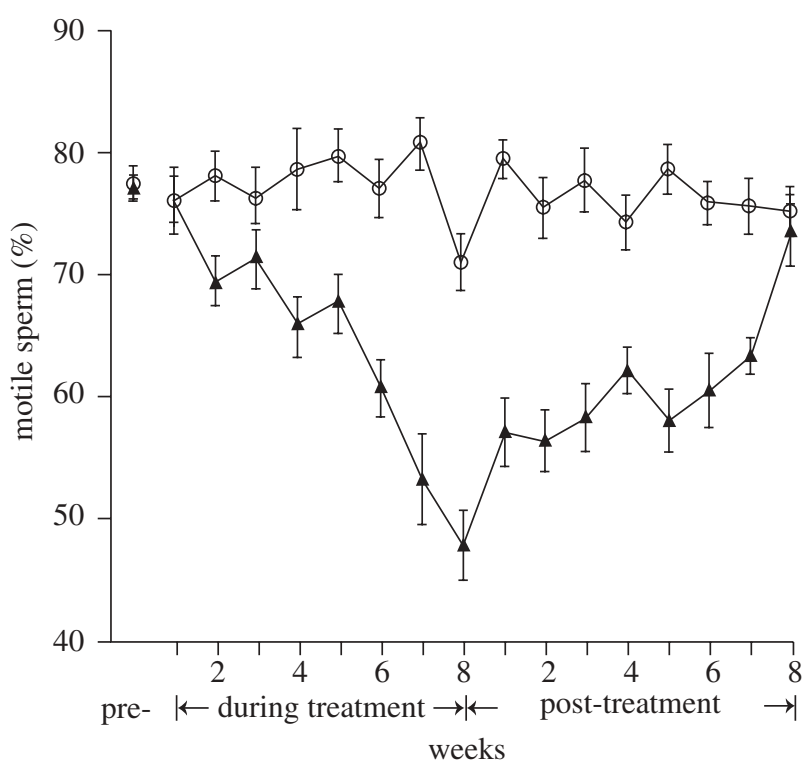

Figure 3. Time course of effects of heat stress on motility of ejaculated spermatozoa in bulls. Control bulls (circles) were maintained in a chamber at $23 \pm 1^{\circ} \mathrm{C}$ for 16 weeks. Heatstressed bulls (triangles) were maintained for 8 weeks in a chamber that was at $31 \pm 1^{\circ} \mathrm{C}$ for $8 \mathrm{~h}$ and $35 \pm 1^{\circ} \mathrm{C}$ for $16 \mathrm{~h}$ of each $24 \mathrm{~h}$ day. Thereafter, heat-stressed bulls were returned to an environment of $23 \pm 1^{\circ} \mathrm{C}$ for 8 weeks. The figure is adapted from Meyerhoeffer et al. (1985) with permission from fournal of Animal Science.

(Pérez-Crespo et al. 2008). In contrast, incubation of sperm at $40^{\circ} \mathrm{C}$ for $4 \mathrm{~h}$ when compared with $38.5^{\circ} \mathrm{C}$ tended to reduce the proportion of embryos that were female following in vitro fertilization (Hendricks et al. 2009).

\section{(b) Hormone secretion}

There are few experiments on the effects of elevated environmental temperature on the secretion of hormones controlling reproductive function. Data from both bulls and boars indicate that heat stress causes an initial decline in circulating concentrations of testosterone lasting two weeks but that concentrations become restored even in the face of continued heat stress (Rhynes \& Ewing 1973; Wettemann \& Desjardins 1979). Hyperthermia can alter luteinizing hormone (LH) secretion in females, even in the absence of ovarian steroids (Schillo et al. 1978), and it is likely that severe heat stress can compromise LH secretion in males as well. However, the major site for disruption of reproductive function appears to be the spermatogenic cell lineage in the testis.

\section{THE FEMALE}

\section{(a) The oocyte}

As for male gametes, heat stress can disrupt development and function of the oocyte. The best evidence for this statement comes from the lactating dairy cow. In this animal, which is particularly sensitive to heat stress because of the metabolic demands of lactation, oocyte competence for fertilization and subsequent development is reduced during times of the year associated with heat stress (Zeron et al. 2001; Al-Katanani et al. 2002; Sartori et al. 2002). There is 
abundant evidence that heat stress can compromise the oocyte and the follicle in which it is encased. High air temperatures 10 days before oestrus were associated with low fertility (Al-Katanani et al. 1999). Steroid production by cultured granulosa and thecal cells was low when cells were obtained from cows exposed to heat stress $20-26$ days previously (Roth et al. 2001a), i.e. when follicles were $0.5-1 \mathrm{~mm}$ in diameter. Moreover, the resumption of fertility seen in lactating dairy cows in Israel in the autumn could be hastened by removing follicles formed in the summer (Roth et al. 2001b).

The mechanism by which heat stress during oogenesis compromises oocyte function is likely to involve alterations in follicular function. Heat stress can alter follicular growth (Roth et al. 2000), steroid secretion (Wolfenson et al. 1997; Roth et al. 2001a; Ozawa et al. 2005) and gene expression (Argov et al. 2005). In goats, heat stress reduced plasma concentrations of oestradiol and lowered follicular oestradiol concentration, aromatase activity and $\mathrm{LH}$ receptor level, and delayed ovulation (figure 4; Ozawa et al. 2005). In rats, heat stress reduced the levels of gonadotropin receptors and aromatase activity of granulosa cells and the follicular fluid concentrations of oestradiol (Shimizu et al. 2005).

Effects of heat stress on follicular function could involve changes at the level of the follicle or the secretion of the pituitary hormones that control development of the follicle. Cultured follicular cells experience reduced steroid production at elevated temperature, at least in cattle (Wolfenson et al. 1997; Bridges et al. 2005). Also, follicular responsiveness to $\mathrm{LH}$, as measured by oestradiol release after injection of gonadotropin releasing hormone injection, was reduced by heat stress in goats (Kanai et al. 1995). Heat stress can reduce LH secretion (Schillo et al. 1978; Wise et al. 1988). One of the consequences of heat stress in lactating dairy cows is increased numbers of small and medium follicles; recruitment of these follicles into the growing pool seems to be due to a decrease in circulating concentrations of inhibin and increased FSH secretion (Roth et al. 2000).

The oocyte remains susceptible to heat stress through the preovulatory period. As shown in cows (Putney et al. 1989) and mice (Baumgartner \& Chrisman 1988; Aroyo et al. 2007; Roth et al. 2008), experimental heat stress coincident with ovulation and oocyte maturation may or may not have an effect on the capacity of oocytes to be fertilized but the resultant embryos are more likely to develop slowly or abnormally. Damage to the oocyte during the preovulatory period could reflect hormonal perturbations. In addition, the process of oocyte maturation is disrupted at elevated temperature (Ju \& Tseng 2004; Payton et al. 2004; Roth \& Hansen 2005; Wang et al. 2009). Damage to the oocyte during the preovulatory period by heat shock seems to involve the generation of reactive oxygen species, as both the effects of heat stress in vivo (Roth et al. 2008) and heat shock in vitro (Lawrence et al. 2004) were reduced by administration of antioxidants. Apoptosis plays a critical role in effects of thermal stress on the maturing oocyte in cattle. A fraction (approx. 15-30\%) of oocytes exposed to elevated temperature undergoes apoptosis as
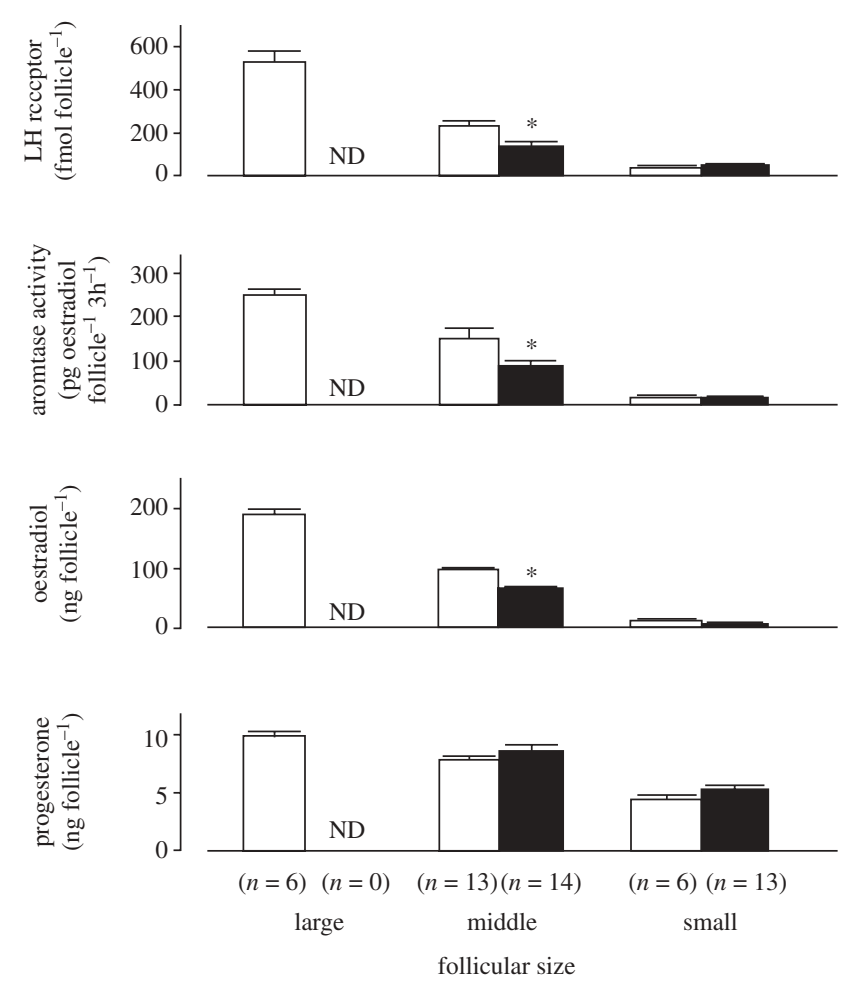

Figure 4. Effects of heat stress on characteristics of follicles during the peri-ovulatory period in goats. Goats were heat stressed (black bar) or not (open bar) for $48 \mathrm{~h}$, treated with prostaglandin $\mathrm{F}-2 \alpha$ and after 48 additional hours, follicles that had been recruited in the past $24 \mathrm{~h}$ were collected and analysed. ND, not determined; $*, p<0.05$. The figure is adapted from Ozawa et al. (2005) with permission from Reproduction.

determined by TUNEL labelling of the pronucleus (Roth \& Hansen 2004a,b, 2005; Soto \& Smith 2009). Inhibition of heat-shock-induced apoptosis with a caspase inhibitor (Roth \& Hansen 2004a), sphingosine 1-phosphate (Roth \& Hansen 2004b, 2005) or a BH4 peptide (Soto \& Smith 2009) reduced the effect of elevated culture temperature on oocyte competence for fertilization and subsequent development (figure 5).

\section{(b) Embryonic development}

The preimplantation embryo is susceptible to maternal heat stress but the susceptibility declines as development proceeds. In cattle, for example, Ealy et al. (1993) found that exposure of lactating cows to heat stress at day 1 after oestrus, when embryos were one to two cells, reduced the proportion of embryos that developed to the blastocyst stage at day 8 after oestrus. However, heat stress at days $3(8-16$ cells), 5 (morula) and 7 (blastocysts) had no effect on the proportion of embryos that were blastocysts at day 8 . A similar pattern of developmental acquisition of thermal resistance occurs in sheep (Dutt 1964) and pigs (Tompkins et al. 1967). The adverse effects of heat shock on cultured embryos also is reduced as they become more advanced in development, at least in the cow (Edwards \& Hansen 1997; Krininger et al. 2002; Sakatani et al. 2004) (figure 6). In contrast, there is no large difference in sensitivity to elevated culture temperatures between mouse embryos at the 

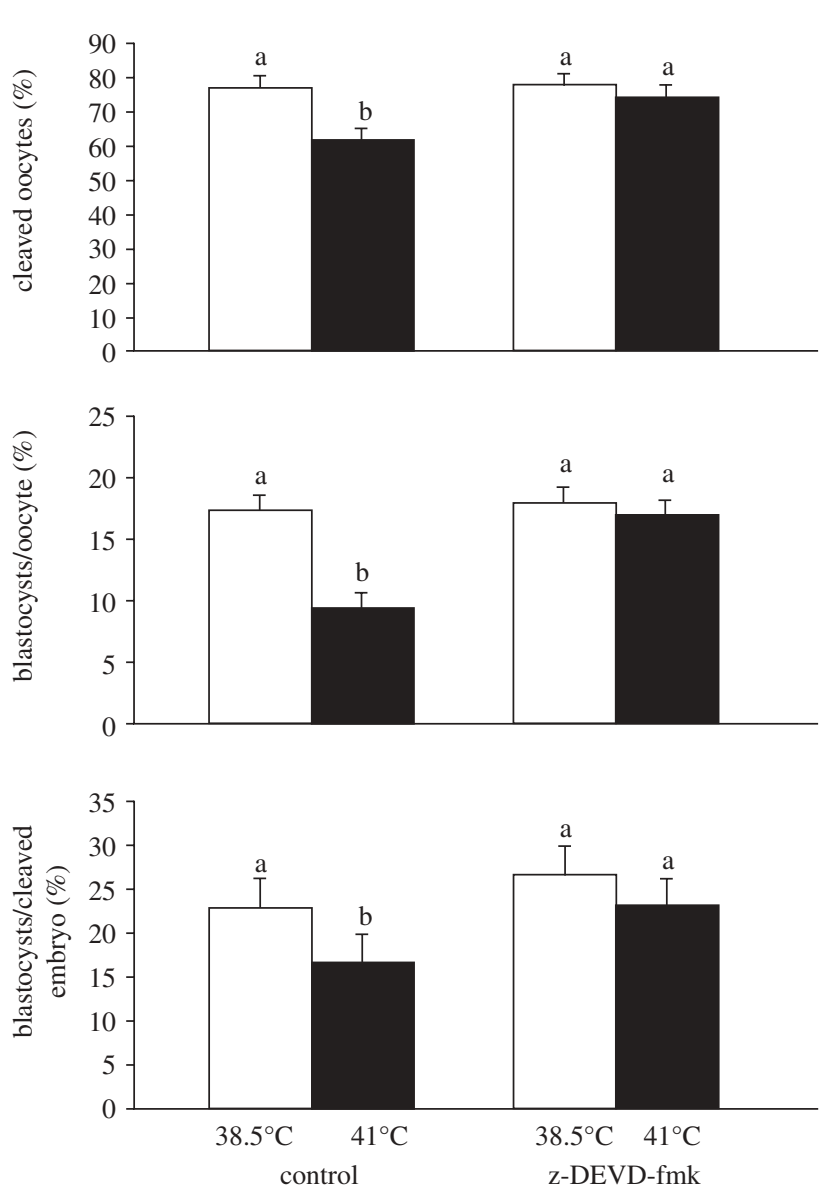

Figure 5. Inhibition of apoptosis with the caspase inhibitor z-DEVD-fmk reduces the effects of heat shock on oocyte maturation. Bovine oocytes were matured at either $38.5^{\circ} \mathrm{C}$ or $41^{\circ} \mathrm{C}$ in the presence or absence of z-DEVD-fmk. Subsequently, oocytes were fertilized and the resultant embryos cultured until determination of blastocyst development at day 8 after insemination. Note that the effects of heat shock during maturation on cleavage and the proportion of oocytes or cleaved embryos that became blastocysts was reduced in the presence of the inhibitor. The figure is adapted from Roth \& Hansen (2004a) with permission from Biology of Reproduction.

two-cell, four-cell and morula stages of development (Aréchiga \& Hansen 1998).

Some actions of elevated temperature on the preimplantation embryo probably involve increased production of reactive oxygen species. The best evidence for this idea comes from the mouse. Maternal heat stress resulted in increased reactive oxygen species activity in oviducts and embryos (Ozawa et al. 2002; Matsuzuka et al. 2005a,b) and reduced glutatione content in recovered embryos (Ozawa et al. 2002; Matsuzuka et al. 2005b). Moreover, treatment of female mice with either melatonin (Matsuzuka et al. 2005 b) or vitamin E (Sakamoto et al. 2008) reduced the effects of heat stress on embryonic development. Female embryos are better able to survive effects of elevated temperature than male mice and this gender difference has been demonstrated to be caused by reduced reactive oxygen species production in females (Pérez-Crespo et al. 2005). Increased reactive oxygen species production in response to elevated culture temperature has also been reported for cattle (Sakatani

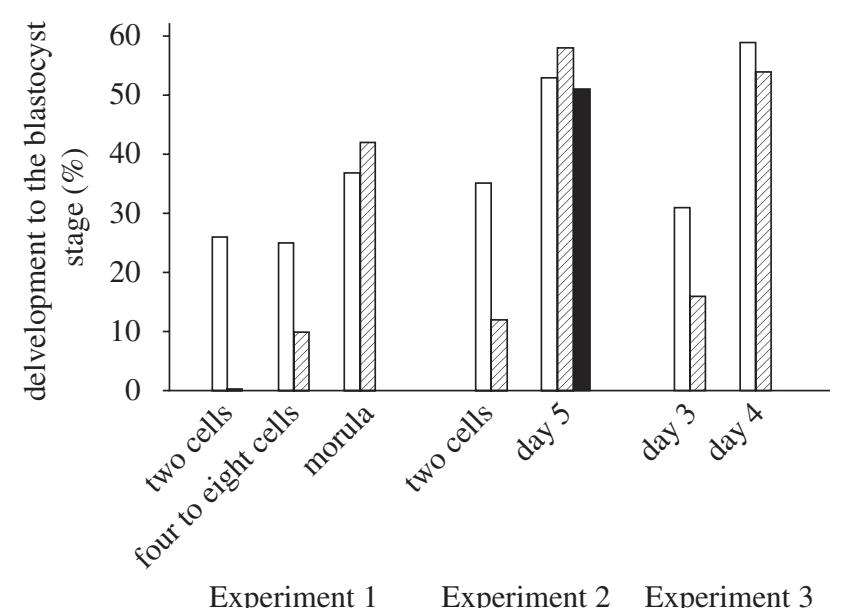

Figure 6. Bovine preimplantation embryos become more resistant to heat shock as development advances. Shown are the results of three experiments (Experiment 1, Edwards \& Hansen 1997; Experiment 2, Krininger et al. 2002; Experiment 3, Sakatani et al. 2004) where embryos at various stages of development or days after insemination were cultured at $38.5-39^{\circ} \mathrm{C}$ (open bars) or at an elevated culture temperature of $41^{\circ} \mathrm{C}$ for $12 \mathrm{~h}$ (hatched bar, Experiment 1), $41^{\circ} \mathrm{C}$ for $6 \mathrm{~h}$ (hatched bar) or $9 \mathrm{~h}$ (filled bar) (Experiment 2) or $43^{\circ} \mathrm{C}$ for $1 \mathrm{~h}$ (hatched, Experiment 3). The figure is adapted from Hansen (2007) with permission from Theriogenology.

et al. 2004, 2008) and treatment with the antioxidant 2-mercaptoethanol has been reported to alleviate the negative effects of heat shock on development in one study (Sakatani et al. 2008), although not in another (de Castro e Paula \& Hansen 2008).

There are several reasons why embryos gain resistance to elevated temperature as development proceeds. Generation of reactive oxygen species in response to heat shock declines as bovine embryos advance in development (Sakatani et al. 2004) while intracellular concentrations of the cytoplasmic antioxidant glutathione increase ( $\mathrm{Lim}$ et al. 1996). In addition, there is developmental regulation in the capacity of the embryo to undergo the induced thermotolerance response, whereby exposure to a mild elevation in temperature makes cells more resistant to a subsequent severe elevation in temperature. This phenomenon does not develop until day 4 in cattle (Paula-Lopes \& Hansen 2002a) and the eight-cell stage in mice (Aréchiga et al. 1995). Acquisition of the capacity for induced thermotolerance involves synthesis of heat shock protein 70 (HSP70). This protein, which stabilizes intracellular proteins and organelles and inhibits apoptosis (Brodsky \& Chiosis 2006), can be induced by elevated temperature as early as the two-cell stage in cattle (Edwards \& Hansen 1996) and mice (Christians et al. 1997), i.e. before induced thermotolerance is acquired. Therefore, other molecular systems must be involved. Glutathione is required for induced thermotolerance in mice (Aréchiga et al. 1995) and changes in redox status may be an important determinant of development of induced thermotolerance.

Inhibition of apoptosis in bovine embryos with a caspase inhibitor increased the magnitude of the reduction in development caused by elevated 
temperature (Paula-Lopes \& Hansen 2002b). Thus, apoptosis, if limited to the most damaged cells of the embryo, may allow the embryo to continue to develop after an environmental insult. In cattle, induction of apoptosis by elevated temperature does not occur until the 8-16 cell stage at day 4 after insemination (Paula-Lopes \& Hansen 2002a).

Some effects of elevated temperature on embryonic survival in utero could be the result of changes in maternal physiology rather than a direct effect on the embryo. In particular, there are reports that heat stress can reduce circulating concentrations of progesterone (see Wolfenson et al. 2000 for review).

\section{(c) Foetal development}

Heat stress during gestation causes reduced foetal growth. The mechanisms involved in this phenomenon have been best characterized in sheep. Exposure of pregnant ewes to heat stress causes reduced foetal and placental weights and concentrations of placental hormones in the blood; effects on growth are greater when occurring during midgestation than when occurring during later gestation (see Wallace et al. 2005 for review). Some effects of heat stress on placental function represent redistribution of blood to the periphery and reduced perfusion of the placental vascular bed (Alexander et al. 1987). However, reduced perfusion to the placenta is not the only cause of reduced foetal weights because placental blood flow per gram of foetus was similar between heat-stressed and control ewes in the study of Wallace et al. (2005). Perhaps more important is an increase in vascular resistance in the placenta (Galan et al. 2005) caused by alterations in angiogenesis as reflected by aberrant patterns of expression of genes such as vascular endothelial growth factor and its receptors and placental growth factor (Regnault et al. 2002). Heat stress probably has more effects during mid-gestation than late gestation because angiogenesis is more extensive in the former period. Glucose transport capacity across the placenta is also reduced by maternal heat stress (Thureen et al. 1992) and this effect involves reduced expression of GLUT8 genes in cotyledonary placenta (Limesand et al. 2004).

Similar effects of maternal heat stress on placental function and foetal development occur in the cow (Collier et al. 1982). In this species, and presumably others, reduced secretion of placental hormones as a result of heat stress can cause reduced milk yield (Collier et al. 1982; Wolfenson et al. 1988). Therefore, inadequate nutrition for the neonate could conceivably be one consequence of maternal heat stress during gestation.

Maternal hyperthermia can also increase the incidence of teratologies (Graham et al. 1998). Even in the absence of such gross developmental defects, it is possible that foetal stress caused by hyperthermia results in changes in physiological function in adulthood. The idea that events in foetal life affect physiology during adult life (Barker 2007) is now well accepted, although there is little information about the specific case of maternal heat stress. One

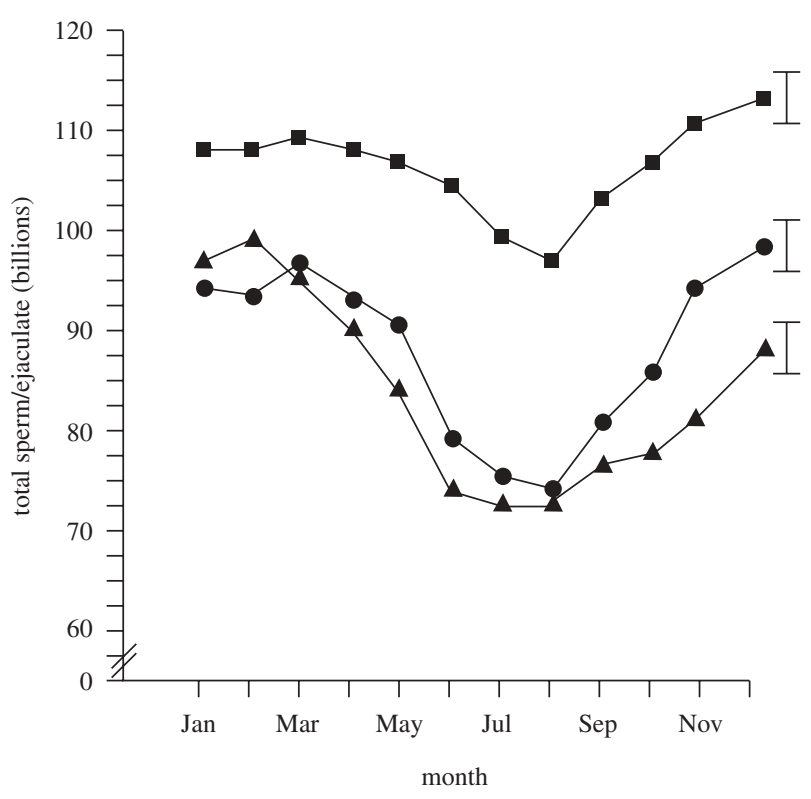

Figure 7. Differences between genetic lines of boars in seasonal variation in sperm output per ejaculate. Square, genetic line $\mathrm{A}$; triangle, genetic line $\mathrm{B}$; circle, genetic line $\mathrm{C}$. The figure is adapted from Flowers (2008) with permission from Theriogenology.

example is for guinea pigs, where heat stress in utero reduced learning activity in adulthood (Jonson et al. 1976).

\section{GENETIC PLASTICITY CONTROLLING THE MAGNITUDE OF HEAT STRESS EFFECTS}

The gene pools of mammals contain allelic variants of specific genes that control body temperature regulation and cellular responsiveness to hyperthermia. Thus, genetic selection, both natural and artificial, can modulate the impact of heat stress on reproductive function.

The importance of genetics for controlling reproductive response to heat stress is illustrated in figure 7 which shows genetic differences among lines of boars in seasonal variation in sperm output. While all three genetic lines of boars experienced a decrease in sperm concentration in the ejaculate during the summer, the magnitude of the decrease was less for line A than for the other lines and the duration of the decreased sperm output during summer was longer for line B than for lines A or C (Flowers 2008).

Genetic influences on regulation of body temperature have been well studied in cattle. In this species, estimates of the heritability of rectal temperature range from 0.25 to $0.65^{\circ} \mathrm{C}$ (Finch 1986). There are distinct breed differences in thermoregulatory ability (Hammond et al. 1996; Hansen 2004; Pereira et al. 2008). One specific gene affecting body temperature regulation during heat stress, the slick gene affecting hair length, has been identified (Olson et al. 2003; Dikmen et al. 2008) and there are undoubtedly others. The superior thermoregulatory ability of zebu cattle has been ascribed to lower metabolic rate, reduced resistance to heat flow from the body core to the periphery and properties of the hair coat (Hansen 2004). 

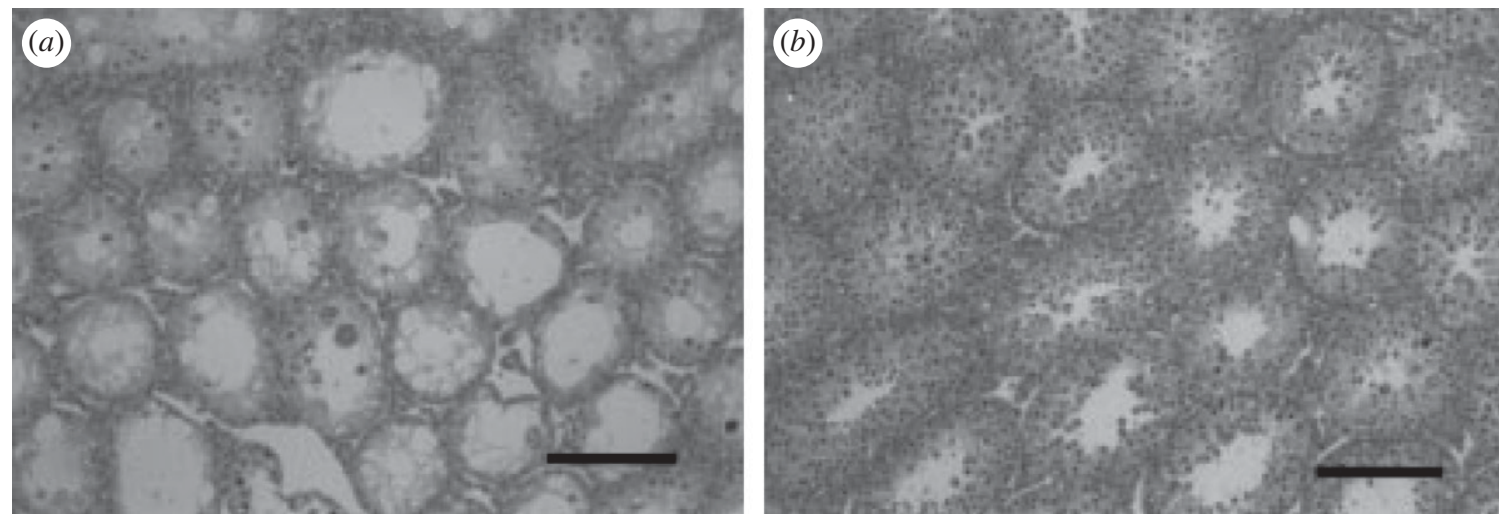

Figure 8. Strain differences in mice for testicular changes following surgical cryptorchidism. Shown are cross sections of testicular tissue from (a) C57/BL6 and (b) MRL/Mpj mice. Note that the seminiferous tubules were larger in MRL/mpj mice and that germ cells were more abundant including spermatocytes and spermatids. The figure is adapte from Kon \& Endoh (2001) with permission from Reproduction, Fertility and Development.

Genetic variability also exists for tissue resistance to elevated temperature. The adverse effect of heat shock on development of preimplantation bovine embryos was less for breeds of cattle that evolved in hot climates (Brahman, Romosinuano, Nelore) than for breeds that evolved in cooler climates (Angus, Holstein) (PaulaLopes et al. 2003; Hernández-Cerón et al. 2004; Barros et al. 2006). In addition, the fertility of Holstein cows inseminated during heat stress was greater if semen was from bulls of the Gyr breed, a Bos indicus, than if semen was from Holstein bulls (Pegorer et al. 2007).

In mice, there are strain differences in the testicular response to cryptorchidism (Kon \& Endoh 2001; Kazusa et al. 2004) and scrotal heating (Li et al. 2009). For example, surgical cryptorchidism of males from A/J BALB/c, $\mathrm{C} 3 \mathrm{H} / \mathrm{He}$, and $\mathrm{C} 57 \mathrm{BL} / 6$ strains resulted in loss of most germ cells and a reduction in testicular size of between 56 and 62 per cent compared with the control testis maintained in the scrotum. For mice of the MRL/Mpj strain, large numbers of germ cells remained in the cryptorchid testis and the reduction in size compared to the control testis was only 31 per cent (figure 8 ) (Kon \& Endoh 2001). Similarly, scrotal heating of $43^{\circ} \mathrm{C}$ induced germ cell apoptosis and loss in both $\mathrm{C} 57 \mathrm{BL} / 6$ and $\mathrm{AKR} / \mathrm{N}$ males but the magnitude of the effects was greater for C57BL/6 (Li et al. 2009). The resistance of germ cells of $\mathrm{MRL} / \mathrm{Mpj}$ mice to elevated testicular temperature may be caused by a mutation in exonuclease-1 (Namiki et al. 2003).

\section{SYNOPSIS: CONSEQUENCES OF ACTIONS OF CLIMATE CHANGE ON REPRODUCTION FOR SPECIES SURVIVAL AND DISTRIBUTION}

Clearly, heat stress can have large effects on most aspects of reproductive function-male and female gamete formation and function, embryonic development and foetal growth and development. The potential impact of heat stress on a mammalian population can be seen by examining seasonal trends in reproductive function of livestock species. In a study in Spain, for example, where heat stress is frequent in the summer, the proportion of inseminated dairy cows that become pregnant during the warm months of the year was 22.1 versus 43.1 per cent of cows inseminated in the cool season (López-Gatius 2003). One must be cautious in extrapolating data from domesticated animals used for food production to wild populations of animals because selection for growth or milk yield increases metabolic rate and exacerbates the problem of body temperature regulation during heat stress. Indeed, the magnitude of the summer decline in fertility is much less for non-lactating heifers or cows producing low amounts of milk than it is for cows with high milk yield (Badinga et al. 1985; Al-Katanani et al. 1999). Thus, it is likely that the direct impact of global warming (i.e. consequences for body temperature regulation) on mammalian reproduction will be more severe for domestic animals than for wild mammalian species. In addition, the existence of allelic variation in genes controlling body temperature regulation and cellular resistance to heat shock means that genetic adaptation to increasing global temperature will be possible for many species.

The author's research on this topic was supported by National Research Initiative Competitive Grants Program grant no. 2007-35203-18070 from the US Department of Agriculture Cooperative State Research, Education and Extension Service and by Research grant no. US-3986-07 from BARD, the Binational Agricultural Research and Development Fund.

\section{REFERENCES}

Alexander, G., Hales, J. R. S., Stevens, D. \& Donnelly, J. B. 1987 Effects of acute and prolonged exposure to heat on regional blood flows in pregnant sheep. F. Dev. Physiol. 9, $1-15$.

Al-Katanani, Y. M., Webb, D. W. \& Hansen, P. J. 1999 Factors affecting seasonal variation in 90 day non-return rate to first service in lactating Holstein cows in a hot climate. F Dairy Sci. 82, 2611-2615.

Al-Katanani, Y. M., Paula-Lopes, F. F. \& Hansen, P. J. 2002 Effect of season and exposure to heat stress on oocyte competence in Holstein cows. F. Dairy Sci. 85, 390-396.

Aréchiga, C. F. \& Hansen, P. J. 1998 Response of preimplantation murine embryos to heat shock as modified by developmental stage and glutathione status. In Vitro Cell Dev. Biol. Anim. 34, 655-659. (doi:10.1007/s11626-9960016-8) 
Aréchiga, C. F., Ealy, A. D. \& Hansen, P. J. 1995 Evidence that glutathione is involved in thermotolerance of preimplantation mouse embryos. Biol. Reprod. 52, 1296-1301. (doi:10.1095/biolreprod52.6.1296)

Argov, N., Moallem, U. \& Sklan, D. 2005 Summer heat stress alters the mRNA expression of selective-uptake and endocytotic receptors in bovine ovarian cells. Theriogenology 64, 1475-1489. (doi:10.1016/j.theriogenology. 2005.02.014)

Aroyo, A., Yavin, S., Arav, A. \& Roth, Z. 2007 Maternal hyperthermia disrupts developmental competence of follicle-enclosed oocytes: in vivo and ex vivo studies in mice. Theriogenology 67, 1013-1021. (doi:10.1016/j.theriogenology.2006.12.001)

Badinga, L., Collier, R. J., Thatcher, W. W. \& Wilcox, C. J. 1985 Effects of climatic and management factors on conception rate of dairy cattle in subtropical environment. 7. Dairy Sci. 68, 78-85.

Barker, D. J. 2007 The origins of the developmental origins theory. F Intern. Med. 261, 412-417. (doi:10.1111/j. 1365-2796.2007.01809.x)

Barros, C. M., Pegorer, M. F., Vasconcelos, J. L., Eberhardt, B. G. \& Monteiro, F. M. 2006 Importance of sperm genotype (indicus versus taurus) for fertility and embryonic development at elevated temperatures. Theriogenology 65, 210-218. (doi:10.1016/j.theriogenology.2005.09.024)

Baumgartner, A. P. \& Chrisman, C. L. 1988 Analysis of post-implantation mouse embryos after maternal heat stress during meiotic maturation. F. Reprod. Fertil. 84, 469-474.

Bedford, J. M. 2004 Enigmas of mammalian gamete form and function. Biol. Rev. 79, 429-460. (doi:10.1017/ S146479310300633X)

Bridges, P. J., Brusie, M. A. \& Fortune, J. E. 2005 Elevated temperature (heat stress) in vitro reduces androstenedione and estradiol and increases progesterone secretion by follicular cells from bovine dominant follicles. Domest. Anim. Endocrinol. 29, 508-522. (doi:10.1016/j. domaniend.2005.02.017)

Brodsky, J. L. \& Chiosis, G. 2006 Hsp70 molecular chaperones: emerging roles in human disease and identification of small molecule modulators. Curr. Top. Med. Chem. 6, 1215-1225. (doi:10.2174/156802606777811997)

Burfening, P. J. \& Ulberg, L. C. 1968 Embryonic survival subsequent to culture of rabbit spermatozoa at $38^{\circ}$ and $40^{\circ}$ C. F. Reprod. Fertil. 15, 87-92.

Christians, E., Michel, E., Adenot, P., Mezger, V., Rallu, M., Morange, M. \& Renard, J. P. 1997 Evidence for the involvement of mouse heat shock factor 1 in the atypical expression of the HSP70.1 heat shock gene during mouse zygotic genome activation. Mol. Cell. Biol. 17, $778-788$.

Collier, R. J., Doelger, S. G., Head, H. H., Thatcher, W. W. \& Wilcox, C. J. 1982 Effects of heat stress during pregnancy on maternal hormone concentrations, calf birth weight and postpartum milk yield of Holstein cows. F. Anim. Sci. 54, 309-319.

de Castro e Paula, L. A. \& Hansen, P. J. 2008 Modification of actions of heat shock on development and apoptosis of cultured preimplantation bovine embryos by oxygen concentration and dithiothreitol. Mol. Reprod. Dev. 75, 1338-1350. (doi:10.1002/mrd.20866)

Dikmen, S., Alava, E., Pontes, E., Fear, J. M., Dikmen, B. Y., Olson, T. A. \& Hansen, P. J. 2008 Differences in thermoregulatory ability between slick-haired and wild-type lactating Holstein cows in response to acute heat stress. f. Dairy Sci. 91, 3395-3402. (doi:10.3168/jds.2008-1072)

Dutt, R. H. 1964 Detrimental effects of high ambient temperature on fertility and early embryo survival in sheep. Int. F. Biometeorol. 8, 47-56. (doi:10.1007/BF02186927)
Ealy, A. D., Drost, M. \& Hansen, P. J. 1993 Developmental changes in embryonic resistance to adverse effects of maternal heat stress in cows. F. Dairy Sci. 76, 2899-2905.

Edwards, J. L. \& Hansen, P. J. 1996 Elevated temperature increases heat shock protein 70 synthesis in bovine twocell embryos and compromises function of maturing oocytes. Biol. Reprod. 55, 340-346.

Edwards, J. L. \& Hansen, P. J. 1997 Differential responses of bovine oocytes and preimplantation embryos to heat shock. Mol. Reprod. Dev. 46, 138-145. (doi:10.1002/ (SICI) 1098-2795(199702)46:2<138::AID-MRD4>3.0. CO;2-R)

Finch, V. A. 1986 Body temperature in beef cattle: its control and relevance to production in the tropics. F. Anim. Sci. 62, 531-542.

Flowers, W. L. 2008 Genetic and phenotypic variation in reproductive traits of AI boars. Theriogenology 70, 1297-1303. (doi:10.1016/j.theriogenology.2008.06.016)

Gaeth, A. P., Short, R. V. \& Renfree, M. B. 1999 The developing renal, reproductive, and respiratory systems of the African elephant suggest an aquatic ancestry. Proc. Natl Acad. Sci. USA 96, 5555-5558. (doi:10.1073/pnas.96. 10.5555)

Galan, H. L., Anthony, R. V., Rigano, S., Parker, T. A., de Vrijer, B., Ferrazzi, E., Wilkening, R. B. \& Regnault, T. R. 2005 Fetal hypertension and abnormal Doppler velocimetry in an ovine model of intrauterine growth restriction. Am. F. Obstet. Gynecol. 192, 272-279. (doi:10.1016/j.ajog.2004.05.088)

Graham Jr, J. M., Edwards, M. J. \& Edwards, M. J. 1998 Teratogen update: gestational effects of maternal hyperthermia due to febrile illnesses and resultant patterns of defects in humans. Teratology 58, 209-221. (doi:10.1002/(SICI) 1096-9926(199811)58:5<209::AIDTERA 8 > 3.0.CO;2-Q)

Hammond, A. C., Olson, T. A., Chase Jr, C. C., Bowers, E. J., Randel, R. D., Murphy, C. N., Vogt, D. W. \& Tewolde, A. 1996 Heat tolerance in two tropically adapted Bos taurus breeds, Senepol and Romosinuano, compared with Brahman, Angus, and Hereford cattle in Florida. F. Anim. Sci. 74, 295-303.

Hansen, P. J. 2004 Physiological and cellular adaptations of zebu cattle to thermal stress. Anim. Reprod. Sci. 82-83, 349-360. (doi:10.1016/j.anireprosci.2004.04.011)

Hansen, P. J. 2007 To be or not to be-determinants of embryonic survival following heat shock. Theriogenology 68(Suppl. 1), S40-S48.

Heldmaier, G., Ortmann, S. \& Elvert, R. 2004 Natural hypometabolism during hibernation and daily torpor in mammals. Respir. Physiol. Neurobiol. 141, 317-329. (doi:10.1016/j.resp.2004.03.014)

Hendricks, K. E. M. \& Hansen, P. J. 2009 Can programmed cell death be induced in post-ejaculatory bull and stallion spermatozoa? Theriogenology 71, 1138-1146. (doi:10. 1016/j.theriogenology.2008.12.006)

Hendricks, K. E. M., Martins, L. \& Hansen, P. J. 2009 Consequences for the bovine embryo of being derived from a spermatozoan subjected to post-ejaculatory aging and heat shock: development to the blastocyst stage and sex ratio. F. Reprod. Dev. 55, 69-74. (doi:10.1262/jrd.20097)

Hernández-Cerón, J., Chase Jr, C. C. \& Hansen, P. J. 2004 Differences in heat tolerance between preimplantation embryos from Brahman, Romosinuano, and Angus Breeds. F. Dairy Sci. 87, 53-58.

Howarth Jr, B., Alliston, C. W. \& Ulberg, L. C. 1965 Importance of uterine environment on rabbit sperm prior to fertilization. F. Anim. Sci. 24, 1027-1032.

Ishii, T., Matsuki, S., Iuchi, Y., Okada, F., Toyosaki, S., Tomita, Y., Ikeda, Y. \& Fujii, J. 2005 Accelerated impairment of spermatogenic cells in SOD1-knockout mice 
under heat stress. Free Radic. Res. 39, 697-705. (doi:10. 1080/10715760500130517)

Jannes, P., Spiessens, C., van der Auwera, I., D'Hooghe, T., Verhoeven, G. \& Vanderschueren, D. 1998 Male subfertility induced by acute scrotal heating affects embryo quality in normal female mice. Hum. Reprod. 13, 372-375.

Jardine, D. S. 2007 Heat illness and heat stroke. Pediatr. Rev. 28, 249-258. (doi:10.1542/pir.28-7-249)

Jonson, K. M., Lyle, J. G., Edwards, M. J. \& Penny, R. H. 1976 Effect of prenatal heat stress on brain growth and serial discrimination reversal learning in the guinea pig. Brain Res. Bull. 1, 133-150. (doi:10.1016/03619230(76)90056-3)

Ju, J. C. \& Tseng, J. K. 2004 Nuclear and cytoskeletal alterations of in vitro matured porcine oocytes under hyperthermia. Mol. Reprod. Dev. 68, 125-133. (doi:10. 1002/mrd.20054)

Kanai, Y., Yagyu, N. \& Shimizu, T. 1995 Hypogonadism in heat stressed goats: poor responsiveness of the ovary to the pulsatile LH stimulation induced by hourly injections of a small dose of GnRH. f. Reprod. Dev. 41, 133-139. (doi:10.1262/jrd.41.133)

Kazusa, K., Namiki, Y., Asano, A., Kon, Y., Endoh, D. \& Agui, T. 2004 Differences in spermatogenesis in cryptorchid testes among various strains of mice. Comp. Med. 54, 179-184.

Kon, Y. \& Endoh, D. 2001 Heat-shock resistance in experimental cryptorchid testis of mice. Mol. Reprod. Dev. 58, 216-222. (doi:10.1002/1098-2795(200102)58: $2<216$ ::AID-MRD11>3.0.CO;2-C)

Krininger III, C. E., Stephens, S. H. \& Hansen, P. J. 2002 Developmental changes in inhibitory effects of arsenic and heat shock on growth of preimplantation bovine embryos. Mol. Reprod. Dev. 63, 335-340. (doi:10.1002/ mrd.90017)

Lawrence, J. L., Payton, R. R., Godkin, J. D., Saxton, A. M., Schrick, F. N. \& Edwards, J. L. 2004 Retinol improves development of bovine oocytes compromised by heat stress during maturation. f. Dairy Sci. 87, 2449-2454

Li, Y., Zhou, Q., Hively, R., Yang, L., Small, C. \& Griswold, M. D. 2009 Differential gene expression in the testes of different murine strains under normal and hyperthermic conditions. F. Androl. 30, 325-337.

Lim, J. M., Liou, S. S. \& Hansel, W. 1996 Intracytoplasmic glutathione concentration and the role of $\beta$-mercaptoethanol in preimplantation development of bovine embryos. Theriogenology 46, 429-439. (doi:10.1016/ 0093-691X(96)00165-3)

Limesand, S. W., Regnault, T. R. \& Hay Jr, W. W. 2004 Characterization of glucose transporter 8 (GLUT8) in the ovine placenta of normal and growth restricted fetuses. Placenta 25, 70-77. (doi:10.1016/j.placenta. 2003.08.012)

López-Gatius, F. 2003 Is fertility declining in dairy cattle? A retrospective study in northeastern Spain. Theriogenology 60, 89-99. (doi:10.1016/S0093-691X(02)01359-6)

Matsuzuka, T., Ozawa, M., Nakamura, A., Ushitani, A., Hirabayashi, M. \& Kanai, Y. 2005a Effects of heat stress on the redox status in the oviduct and early embryonic development in mice. F. Reprod. Dev. 51, 281-287. (doi:10.1262/jrd.16089)

Matsuzuka, T., Sakamoto, N., Ozawa, M., Ushitani, A., Hirabayashi, M. \& Kanai, Y. 2005b Alleviation of maternal hyperthermia-induced early embryonic death by administration of melatonin to mice. F. Pineal Res. 39, 217-223. (doi:10.1111/j.1600-079X.2005.00260.x)

Meyerhoeffer, D. C., Wettemann, R. P., Coleman, S. W. \& Wells, M. E. 1985 Reproductive criteria of beef bulls during and after exposure to increased ambient temperature. F. Anim. Sci. 60, 352-357.

Namiki, Y., Endoh, D. \& Kon, Y. 2003 Genetic mutation associated with meiotic metaphase-specific apoptosis in MRL/MpJ mice. Mol. Reprod. Dev. 64, 179-188. (doi:10.1002/mrd.10208)

Olson, T. A., Lucena, C., Chase Jr, C. C. \& Hammond, A. C. 2003 Evidence of a major gene influencing hair length and heat tolerance in Bos taurus cattle. $\mathcal{F}$ Anim. Sci. 81, 80-90.

Ozawa, M., Hirabayashi, M. \& Kanai, Y. 2002 Developmental competence and oxidative state of mouse zygotes heat-stressed maternally or in vitro. Reproduction 124, 683-689. (doi:10.1530/rep.0.1240683)

Ozawa, M., Tabayashi, D., Latief, T. A., Shimizu, T., Oshima, I. \& Kanai, Y. 2005 Alterations in follicular dynamics and steroidogenic abilities induced by heat stress during follicular recruitment in goats. Reproduction 129, 621-630. (doi:10.1530/rep.1.00456)

Paul, C., Murray, A. A., Spears, N. \& Saunders, P. T. 2008 A single, mild, transient scrotal heat stress causes DNA damage, subfertility and impairs formation of blastocysts in mice. Reproduction 136, 73-84. (doi:10.1530/REP-080036)

Paul, C., Teng, S. \& Saunders, P. T. 2009 A single, mild, transient scrotal heat stress causes hypoxia and oxidative stress in mouse testes, which induces germ cell death. Biol. Reprod. 80, 913-919.

Paula-Lopes, F. F. \& Hansen, P. J. 2002a Heat-shock induced apoptosis in preimplantation bovine embryos is a developmentally-regulated phenomenon. Biol. Reprod. 66, 1169-1177.

Paula-Lopes, F. F. \& Hansen, P. J. $2002 b$ Apoptosis is an adaptive response in bovine preimplantation embryos that facilitates survival after heat shock. Biochem. Biophys. Res. Commun. 295, 37-42. (doi:10.1016/ S0006-291X(02)00619-8)

Paula-Lopes, F. F. et al. 2003 Genetic divergence in cellular resistance to heat shock in cattle: differences between breeds developed in temperate versus hot climates in responses of preimplantation embryos, reproductive tract tissues and lymphocytes to increased culture temperatures. Reproduction 125, 285-294. (doi:10.1530/rep.0.1250285)

Payton, R. R., Romar, R., Coy, P., Saxton, A. M., Lawrence, J. L. \& Edwards, J. L. 2004 Susceptibility of bovine germinal vesicle-stage oocytes from antral follicles to direct effects of heat stress in vitro. Biol. Reprod. 71, 1303-1308. (doi:10.1095/biolreprod.104.029892)

Pegorer, M. F., Vasconcelos, J. L., Trinca, L. A., Hansen, P. J. \& Barros, C. M. 2007 Influence of sire and sire breed (Gyr versus Holstein) on establishment of pregnancy and embryonic loss in lactating Holstein cows during summer heat stress. Theriogenology 67, 692-697. (doi:10.1016/j.theriogenology.2006.09.042)

Pereira, A. M., Baccari Jr, F., Titto, E. A. \& Almeida, J. A. 2008 Effect of thermal stress on physiological parameters, feed intake and plasma thyroid hormones concentration in Alentejana, Mertolenga, Frisian and Limousine cattle breeds. Int. F. Biometeorol. 52, 199-208. (doi:10.1007/ s00484-007-0111-x)

Pérez-Crespo, M., Ramírez, M. A., Fernández-González, R., Rizos, D., Lonergan, P., Pintado, B. \& Gutiérrez-Adán, A. 2005 Differential sensitivity of male and female mouse embryos to oxidative induced heat-stress is mediated by glucose-6-phosphate dehydrogenase gene expression. Mol. Reprod. Dev. 72, 502-510. (doi:10.1002/mrd.20366)

Pérez-Crespo, M., Pintado, B. \& Gutiérrez-Adán, A. 2008 Scrotal heat stress effects on sperm viability, sperm DNA integrity, and the offspring sex ratio in mice. Mol. Reprod. Dev. 75, 40-47. (doi:10.1002/mrd.20759) 
Prosser, C. L. \& Heath, J. E. 1991 Temperature. In Comparative animal physiology, environmental and metabolic animal physiology (ed. C. L. Prosser), pp. 109-166, 4th edn. New York, NY: John Wiley \& Sons.

Putney, D. J., Mullins, S., Thatcher, W. W., Drost, M. \& Gross, T. S. 1989 Embryonic development in superovulated dairy cattle exposed to elevated ambient temperatures between the onset of estrus and insemination. Anim. Reprod. Sci. 19, 37-51. (doi:10.1016/0378-4320(89)90045-6)

Regnault, T. R., Orbus, R. J., de Vrijer, B., Davidsen, M. L., Galan, H. L., Wilkening, R. B. \& Anthony, R. V. 2002 Placental expression of VEGF, PlGF and their receptors in a model of placental insufficiency-intrauterine growth restriction (PI-IUGR). Placenta 23, 132-144. (doi:10. 1053/plac.2001.0757)

Rhynes, W. E. \& Ewing, L. L. 1973 Testicular endocrine function in Hereford bulls exposed to high ambient temperature. Endocrinology 92, 509-515. (doi:10.1210/ endo-92-2-509)

Rommel, S. A., Pabst, D. A., McLellan, W. A., Mead, J. G. \& Potter, C. W. 1992 Anatomical evidence for a countercurrent heat exchanger associated with dolphin testes. Anat. Rec. 232, 150-156. (doi:10.1002/ar.1092320117)

Rommel, S. A., Early, G. A., Matassa, K. A., Pabst, D. A. \& McLellan, W. A. 1995 Venous structures associated with thermoregulation of phocid seal reproductive organs. Anat. Rec. 243, 390-402. (doi:10.1002/ar.1092430314)

Roth, Z. \& Hansen, P. J. $2004 a$ Involvement of apoptosis in disruption of oocyte competence by heat shock in cattle. Biol. Reprod. 71, 1898-1906. (doi:10.1095/biolreprod. 104.031690)

Roth, Z. \& Hansen, P. J. $2004 b$ Sphingosine 1-phosphate protects bovine oocytes from heat shock during maturation. Biol. Reprod. 71, 2072-2078. (doi:10.1095/ biolreprod.104.031989)

Roth, Z. \& Hansen, P. J. 2005 Disruption of nuclear maturation and rearrangement of cytoskeletal elements in bovine oocytes exposed to heat shock during maturation. Reproduction 129, 235-244. (doi:10.1530/rep.1.00394)

Roth, Z., Meidan, R., Braw-Tal, R. \& Wolfenson, D. 2000 Immediate and delayed effects of heat stress on follicular development and its association with plasma FSH and inhibin concentration in cows. F. Reprod. Fertil. 120, 83-90. (doi:10.1530/reprod/120.1.83)

Roth, Z., Meidan, R., Shaham-Albalancy, A., Braw-Tal, R. \& Wolfenson, D. 2001a Delayed effect of heat stress on steroid production in medium-sized and preovulatory bovine follicles. Reproduction 121, 745-751. (doi:10. 1530/rep.0.1210745)

Roth, Z., Arav, A., Bor, A., Zeron, Y., Braw-Tal, R. \& Wolfenson, D. $2001 b$ Improvement of quality of oocytes collected in the autumn by enhanced removal of impaired follicles from previously heat-stressed cows. Reproduction 122, 737-744. (doi:10.1530/rep.0.1220737)

Roth, Z., Aroyo, A., Yavin, S. \& Arav, A. 2008 The antioxidant epigallocatechin gallate (EGCG) moderates the deleterious effects of maternal hyperthermia on follicleenclosed oocytes in mice. Theriogenology 70, 887-897. (doi:10.1016/j.theriogenology.2008.05.053)

Sakamoto, N., Ozawa, M., Yokotani-Tomita, K., Morimoto, A., Matsuzuka, T., Ijiri, D., Hirabayashi, M., Ushitani, A. \& Kanai, Y. 2008 DL- $\alpha$-Tocopherol acetate mitigates maternal hyperthermia-induced pre-implantation embryonic death accompanied by a reduction of physiological oxidative stress in mice. Reproduction 135, 489-496. (doi:10.1530/ REP-07-0379)

Sakatani, M., Kobayashi, S. \& Takahashi, M. 2004 Effects of heat shock on in vitro development and intracellular oxidative state of bovine preimplantation embryos. Mol. Reprod. Dev. 67, 77-82. (doi:10.1002/mrd.20014)
Sakatani, M., Yamanaka, K., Kobayashi, S. \& Takahashi, M. 2008 Heat shock-derived reactive oxygen species induce embryonic mortality in in vitro early stage bovine embryos. F. Reprod. Dev. 54, 496-501. (doi:10.1262/jrd. 20017)

Sartori, R., Sartor-Bergfelt, R., Mertens, S. A., Guenther, J. N., Parrish, J. J. \& Wiltbank, M. C. 2002 Fertilization and early embryonic development in heifers and lactating cows in summer and lactating and dry cows in winter. F. Dairy Sci. 85, 2803-2812.

Schillo, K. K., Alliston, C. W. \& Malven, P. V. 1978 Plasma concentrations of luteinizing hormone and prolactin in the ovariectomized ewe during induced hyperthermia. Biol. Reprod. 19, 306-313. (doi:10.1095/biolreprod19.2.306)

Setchell, B. P. 1998 The Parkes Lecture. Heat and the testis. F. Reprod. Fertil. 114, 179-194. (doi:10.1530/jrf.0. 1140179)

Shimizu, T., Ohshima, I., Ozawa, M., Takahashi, S., Tajima, A., Shiota, M., Miyazaki, H. \& Kanai, Y. 2005 Heat stress diminishes gonadotropin receptor expression and enhances susceptibility to apoptosis of rat granulosa cells. Reproduction 129, 463-472. (doi:10.1530/rep.1.00502)

Soto, P. \& Smith, L. C. 2009 BH4 peptide derived from Bcl$\mathrm{xL}$ and Bax-inhibitor peptide suppresses apoptotic mitochondrial changes in heat stressed bovine oocytes. Mol. Reprod. Dev. 76, 637-646.

Thureen, P. J., Trembler, K. A., Meschia, G., Makowski, E. L. \& Wilkening, R. B. 1992 Placental glucose transport in heat-induced fetal growth retardation. Am. F. Physiol. 263, R578-R585.

Tompkins, E. C., Heidenreich, C. J. \& Stob, M. 1967 Effect of post-breeding thermal stress on embryonic mortality in swine. F. Anim. Sci. 26, 377-380.

Wallace, J. M., Regnault, T. R., Limesand, S. W., Hay Jr, W. W. \& Anthony, R. V. 2005 Investigating the causes of low birth weight in contrasting ovine paradigms. F. Physiol. 565, 19-26. (doi:10.1113/jphysiol.2004.082032)

Wang, J. Z., Sui, H. S., Miao, D. Q., Liu, N., Zhou, P., Ge, L. \& Tan, J. 2009 Effects of heat stress during in vitro maturation on cytoplasmic versus nuclear components of mouse oocytes. Reproduction 137, 181-189. (doi:10.1530/REP-08-0339)

Werdelin, L. \& Nilsonne, A. 1999 The evolution of the scrotum and testicular descent in mammals: a phylogenetic view. f Theor. Biol. 196, 61-72. (doi:10.1006/jtbi.1998.0821)

Wettemann, R. P. \& Desjardins, C. 1979 Testicular function in boars exposed to elevated ambient temperature. Biol. Reprod. 20, 235-241. (doi:10.1095/biolreprod20.2.235)

Wise, M. E., Armstrong, D. V., Huber, J. T., Hunter, R. \& Wiersma, F. 1988 Hormonal alterations in the lactating dairy cow in response to thermal stress. F. Dairy Sci. 71, 2480-2485.

Wolfenson, D., Flamenbaum, I. \& Berman, A. 1988 Dry period heat stress relief effects on prepartum progesterone, calf birth weight, and milk production. F. Dairy Sci. 71, 809-818.

Wolfenson, D., Lew, B. J., Thatcher, W. W., Graber, Y. \& Meidan, R. 1997 Seasonal and acute heat stress effects on steroid production by dominant follicles in cows. Anim. Reprod. Sci. 47, 9-19. (doi:10.1016/S03784320(96)01638-7)

Wolfenson, D., Roth, Z. \& Meidan, R. 2000 Impaired reproduction in heat-stressed cattle: basic and applied aspects. Anim. Reprod. Sci. 60-61, 535-547. (doi:10.1016/ S0378-4320(00)00102-0)

Zeron, Y., Ocheretny, A., Kedar, O., Borochov, A., Sklan, D. \& Arav, A. 2001 Seasonal changes in bovine fertility: relation to developmental competence of oocytes, membrane properties and fatty acid composition of follicles. Reproduction 121, 447-454. (doi:10.1530/rep.0.1210447) 